\title{
Comparison of Methods for Restoring Meadows Invaded by Solidago Species
}

\author{
Sebastian Świerszcz ${ }^{1 *}$, Magdalena Szymura ${ }^{1}$, \\ Karol Wolski', Tomasz H. Szymura \\ ${ }^{1}$ Department of Agroecosystems and Green Areas Management, Wrocław University of Environmental \\ and Life Sciences, Wrocław, Poland \\ ${ }^{2}$ Department of Ecology, Biogeochemistry and Environmental Protection, \\ University of Wrocław, Wrocław, Poland
}

Received: 29 September 2016

Accepted: 23 November 2016

\begin{abstract}
Semi-natural meadows are valuable for maintaining biodiversity and providing a range of ecosystem services. The majority of these communities are protected by the European Natura 2000 system. However, grasslands are threatened by invasions by alien species, particularly Solidago spp. The invaders should be eradicated because of their negative impact on biodiversity, the environment, and the economy. A field experiment was conducted to compare the effect of different treatments (scalping, rototilling, and use of herbicide) on restoration of a meadow seriously invaded by Solidago spp. Fresh hay was transferred to the experimental plots to provide target meadow species seeds. Significant differences in species composition and coverage were detected between the herbicide-treated and plots that received other treatments and between the use of a rototiller and the control. Applying the herbicide glyphosate quickly reduced the cover of Solidago spp. $(0.5 \pm 0.4 \%)$ and increased target species cover $(84.8 \pm 13.6 \%)$. The Solidago spp. cover rates were $79.5 \pm 17.1 \%$ and $65 \pm 31.4 \%$ when scalping and rototilling were used, respectively, whereas the target species cover rates were $25.8 \pm 16 \%$ and $30 \pm 15.8 \%$, respectively. The sward that grew after applying glyphosate had the highest forage value and resistance to cutting. These results show that short-term eradication of invasive Solidago spp. and restoration of a meadow are possible using glyphosate. However, use of a herbicide may have a negative impact on the environment and native species.
\end{abstract}

Keywords: invasive species, semi-natural meadows, species composition, hay transfer, restoration

\section{Introduction}

Exotic plant species that spread into natural and seminatural plant communities are a serious threat to native species and affect the structure and dynamics of the

*e-mail: sebastian.swierszcz@upwr.edu.pl vegetation [1]. The majority of invasive plant species are strong competitors that displace native species, decrease biodiversity, and alter ecosystem services [2-3].

Traditional grasslands in Europe include some of the most species-rich habitats and richest soil biodiversity. A grassland provides a range of ecosystem services, from meat and dairy products to recreational and tourism opportunities, and also creates a considerable carbon sink. More than $80 \%$ of semi-natural grasslands have been 
lost in the last 100 years due to intensified production or abandonment. A large number of grassland species have declined or become extinct [4-7]. Therefore, many semi-natural grasslands in the pan-European Nature 2000 network are protected, as specified in Annex I of the Habitat Directive. Despite this protection, the effects of abandoning agriculture remain visible in Central and Eastern Europe. It is an effect of the collapse of the socialist regime in the early 1990s, which caused socioeconomic processes resulting in landscape-scale changes in biodiversity, ecosystem services, and agricultural production [8-10].

Invasion by alien species is among the processes causing the major environmental changes that are destroying biodiversity and the economy [11]. Increased competition with alien species threatens the less competitive European grassland species. In addition, competitive pressure reduces populations of specialized species and, consequently, they are wiped out by negative events, such as fluctuating climatic conditions, predators, loss of genetic diversity in a small population, or disease. In these cases, typical grassland species are likely to become extinct, although not immediately because of the time lag between the introduction of an invasive alien species and the disappearance of native grassland species. Moreover, alien species can attract pollinators and interrupt the mutualistic relationships between insects and native grassland plant species [6, 12-13].

One of the most common invasive plants on European grasslands is alien Solidago spp. Three Solidago spp. are naturalised North American species, such as $S$. gigantea Aiton, S. canadensis L., and S. altissima L. (S. canadensis var. scabra (Muhl.) Torr. and Gray) [14]. These species were introduced to Europe in the 18th century as ornamental plants that escaped from gardens into the natural environment. Nowadays, they are one of the most common invasive species in the world and are most often found on roadsides, railways, abandoned fields, and meadows [15-18]. These species have a strong ability to colonize new sites by producing a large number of light seeds, rapid clonal growth, high environmental plasticity, and high biomass production [16, 19]. The Solidago spp. invading abandoned semi-natural meadows negatively affect species richness and composition of plants and pollinators. Solidago spp. also change soil $\mathrm{pH}$ and nutrient levels, increase organic carbon content, and increase soil bacterial and fungal biomass [20-22]. The high proportion of Solidago spp. in abandoned meadow swards results in poor hay quality due to the high saponin content [16].

Consequently, it is necessary to restore areas occupied by Solidago spp., reducing invasive species over the long term is only possible after removing the invasive plant species and restoring the habitat [23]. Among mechanical methods to eliminate Solidago spp. are mowing, hand pulling, mulching, and ploughing the soil [24-27]. Herbicides produce rapid effects [28-30].

Eradicating invasive species is insufficient to restore a semi-natural grassland, as propagules of target meadow plants must be provided to regenerate the sward and compete effectively with any remaining invasive species [31]. A successful way to provide meadow species seeds is transferring fresh hay. Many studies have shown that plant species richness and the number of target species are higher on plots that have received fresh hay compared to control plots, where sowing of grass species or no seed was applied [32-34]. Moreover, mulching is an effective method to reduce growth and development of Solidago seedlings [16,27], and hay can serve a similar purpose.

Many studies have investigated eliminating Solidago spp. and restoring grasslands, but few studies have been devoted directly to restoring meadows invaded by alien Solidago spp. In this study, we show the results of a field experiment in which grasslands were restored after being invaded by Solidago spp. using different methods to eliminate the Solidago spp. We focused on answering three questions:

1) Which of the treatments was the most effective for removing Solidago spp.?

2) Does applying fresh hay effectively restore the seminatural meadows sward?

3) Which method of removing Solidago spp. combined with fresh hay results in the best forage value of sward?

\section{Material and Methods}

\section{Study Site}

The experiment was established in July 2013 in Wroclaw, Poland (N 51 $09^{\prime} 41,5^{\prime \prime}, \mathrm{E} 17^{\circ} 06^{\prime} 41,5^{\prime \prime}$ ) in an abandoned meadow overgrown by invasive North American Solidago spp. (S. gigantea Aiton. and $S$. canadensis L.). The study site was located at an altitude of $118 \mathrm{~m}$ a.s.l. in a small river valley surrounded by suburban buildings and extensively used meadows. The surrounding meadows were Molinion and Arrhenatherion grasslands according to a phytosociological perspective. The mean annual temperature in the region is $11.6^{\circ} \mathrm{C}$ (maximum in July, $18.8^{\circ} \mathrm{C}$; minimum in January, $-0.8^{\circ} \mathrm{C}$ ), and the mean annual precipitation is $581.4 \mathrm{~mm}$ (maximum in July, $85.7 \mathrm{~mm}$ ), as provided by the Agro- and Hydrometeorology

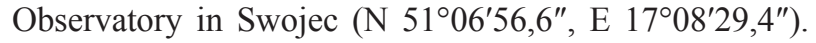
The chemical properties of the soil in the upper layer $(0-15 \mathrm{~cm})$ recorded in 2014 were as follows: $\mathrm{pH}$ (measured in $\mathrm{KCl}$ ) $=6.09$, organic carbon $=29.7 \mathrm{~g} \cdot \mathrm{kg}^{-1}$, total nitrogen $=2.52 \mathrm{~g} \cdot \mathrm{kg}^{-1}$, available forms of phosphorus $=32.73 \mathrm{mg} \cdot \mathrm{kg}^{-1}$, potassium $=51.56 \mathrm{mg} \cdot \mathrm{kg}^{-1}$, and magnesium $=288.94 \mathrm{mg} \cdot \mathrm{kg}^{-1}$.

\section{Experimental Design and Data Collection}

The field experiment was established using a randomised block design with four replications containing $2.5 \times 2.5 \mathrm{~m}$ plots. The distance between blocks was $1 \mathrm{~m}$. Plots within blocks contact each other, but the observations were performed on $2 \times 2 \mathrm{~m}$ plots with a buffer zone between neighbouring plots with different 
Table 1. F- (lower part of the matrix) and $p$ - (upper part of the matrix) values for the post-hoc tests after PERMANOVA between treatments. Significant differences $(p<0.05)$ are marked with an asterisk.

\begin{tabular}{|c|c|c|c|c|c|}
\hline & & \multicolumn{4}{|c|}{$p$-values } \\
\hline \multirow{3}{*}{$F$ - values } & & Scalping & Glyphosate & Rototilling & Control \\
\cline { 2 - 6 } & Scalping & - & $0.027^{*}$ & 0.145 & 0.627 \\
\cline { 2 - 6 } & Glyphosate & 8.779 & - & $0.028^{*}$ & $0.029^{*}$ \\
\cline { 2 - 6 } & Rototilling & 1.369 & 8.536 & - & $0.030^{*}$ \\
\hline
\end{tabular}

treatments. First, the entire experimental area was mowed and the biomass was removed in May 2014. One of the three treatments, including scalping (depth of sod cut approximately $1 \mathrm{~cm}$ ), rototilling and a herbicide (glyphosate, $5 \mathrm{~L} \mathrm{ha}^{-1}$ ), as well as the control (no treatment) was applied to particular plots. Fresh hay was harvested from a meadow with similar habitat conditions and floristic composition as the meadows surrounding the experiment plots and was spread on the experimental plots. The donor site was approximately $30 \mathrm{~km}$ from the experimental site. The fresh hay was collected and applied at the end of July, when most of the target meadow species had mature seeds. Fresh hay was applied at a 1:1 ratio (donor:acceptor site area). In total, 16 plots were analysed (three treatments + control $\times$ four repetitions). The percentage cover of vascular plant species in each of the plots was assessed in June 2014 using a percentage scale.

\section{Data Analysis}

To evaluate the effect of the treatments on species composition, PERMANOVA and a post-hoc test were applied using the PAST package [35]. Non-metric multidimensional scaling (NMDS) ordination was used to visualise the results (CANOCO 5) [36]. The SIMPER test was applied to identify the plant species strongly related to a particular treatment [37]. All data were square root transformed before the computations. The means of the raw data and the transformed data are shown in Table 2 and Appendix 1 [38]. The Bray-Curtis distance was the background for all of the tests mentioned above.

To assess the effect of the treatments on the grassland utilisation value, the means of the mowing tolerance and forage value indicators were calculated for all treatments. The indicator values were determined using a nine-point scale, and mowing tolerance was rated from 1 (intolerant of mowing) to 9 (very tolerant of mowing), whereas the forage value was rated from 1 (poisonous to livestock and humans) to 9 (best forage value). The means weighted by species cover were calculated. The values of the indicators were derived from the BiolFlor database [39]. In addition, species were divided into four ecological groups: invasive Solidago spp. (Solidago), typical meadow species (target), ruderal, and other species. The target species considered were species typical of the Molinio-Arrhenatheretea class, whereas the ruderal species were Stellarietea mediae and Artemisietea vulgaris, according to Matuszkiewicz [40].

Table 2. Results of the SIMPER analysis. Nine species contributed more than $50 \%$ of the differences between treatments and the cumulative percentages (cumulative). The values in columns for particular treatments (scalping, glyphosate, rototilling, and control) show the mean cover of the species in a given treatment. Species that affected differences in the sward after fresh hay was transferred and made use of selected treatments. The analysis was performed on square root transformed data. The means of the raw data are shown in parenthesis. A list of all species is presented in Appendix 1.

\begin{tabular}{|c|c|c|c|c|c|c|c|c|c|c|}
\hline Taxon & $\begin{array}{c}\text { Contrib. } \\
\%\end{array}$ & $\begin{array}{c}\text { Cumulative } \\
\%\end{array}$ & \multicolumn{2}{|c|}{ Scalping } & \multicolumn{2}{|c|}{ Glyphosate } & \multicolumn{3}{|c|}{ Rototilling } & \multicolumn{2}{c|}{ Control } \\
\hline Solidago gigantea & 14.65 & 14.65 & 8.70 & $(76.30)$ & 0.60 & $(0.50)$ & 7.50 & $(60.00)$ & 9.87 & $(97.50)$ \\
\hline Festuca pratensis & 9.68 & 24.33 & 0.60 & $(0.75)$ & 5.97 & $(36.30)$ & 3.03 & $(10.80)$ & 0.35 & $(0.50)$ \\
\hline Poa trivialis & 5.63 & 29.96 & 3.16 & $(11.30)$ & 4.74 & $(23.80)$ & 2.11 & $(4.50)$ & 1.88 & $(5.25)$ \\
\hline Alopecurus pratensis & 5.49 & 35.46 & 0.56 & $(1.25)$ & 3.51 & $(13.80)$ & - & - & 0.25 & $(0.25)$ \\
\hline Solidago canadensis & 3.71 & 39.16 & 1.55 & $(3.25)$ & - & - & 2.24 & $(5.00)$ & 1.16 & $(1.75)$ \\
\hline Vicia hirsuta & 3.54 & 42.70 & 1.91 & $(5.00)$ & 1.43 & $(3.77)$ & 2.16 & $(5.25)$ & 1.44 & $(2.38)$ \\
\hline Artemisia vulgaris & 3.25 & 45.96 & 0.61 & $(0.65)$ & - & - & 2.19 & $(6.63)$ & 0.08 & $(0.03)$ \\
\hline Holcus lanatus & 3.16 & 49.11 & 0.60 & $(0.50)$ & 2.34 & $(5.75)$ & 1.34 & $(2.13)$ & 0.60 & $(0.50)$ \\
\hline Scrophularia nodosa & 2.69 & 51.80 & 0.08 & $(0.03)$ & 0.08 & $(0.03)$ & 1.85 & $(6.38)$ & 0.25 & $(0.25)$ \\
\hline
\end{tabular}




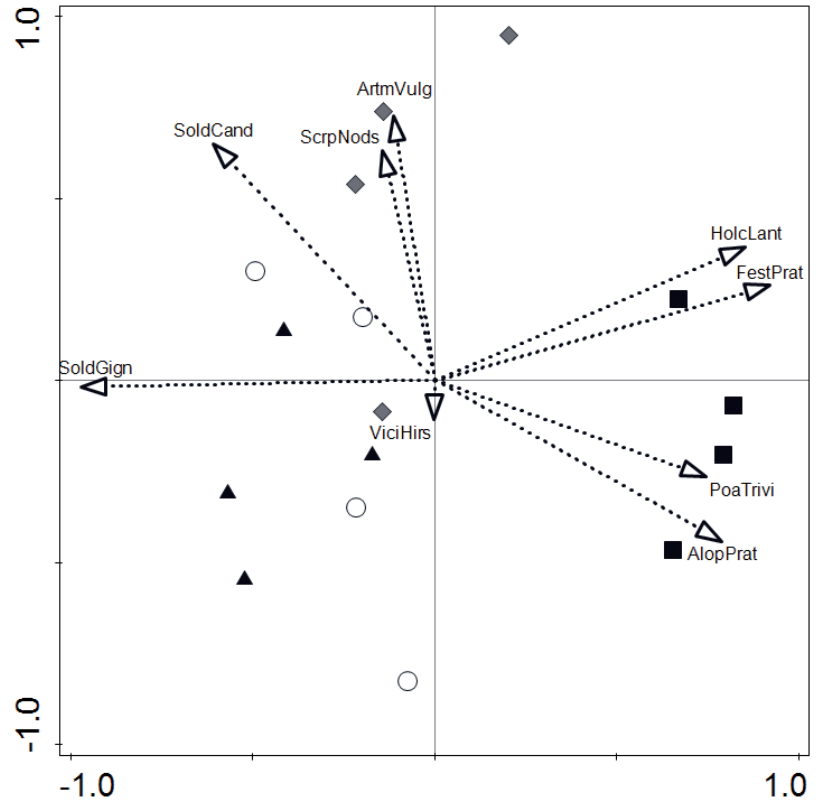

Fig. 1. Non-metric multidimensional scaling (NMDS) ordination based on the Bray-Curtis distance (stress value $=0.129$ ) shows the effect of the treatments on the restored meadow (white circles, scalping; black squares, glyphosate; grey diamonds, rototiller; and black triangles, control). The nine species with the greatest impact on the differences between treatments are shown. Species abbreviations: AlopPrat, Alopecurus pratensis; ArtmVulg, Artemisia vulgaris, FestPrat, Festuca pratensis; HolcLant, Holcus lanatus; PoaTrivi, Poa trivialis; ScrpNods, Scrophularia nodosa; SoldCand, Solidago canadensis; SoldGign, Solidago gigantea; ViciHirs, Vicia hirsuta.

The Kruskal-Wallis rank test was applied to compare these characteristics using Statistica 12 [41].

\section{Results}

\section{Effect of the Treatments on Species Composition}

Species composition in the treatment plots differed significantly $(F=5.737, p=0.0001)$, but no differences were detected between blocks $(F=0.634, p=0.807)$.
Species composition and coverage were significantly different between the glyphosate and remaining treatments as well as between the rototiller treatment and control (Table 1). Nine species contributed to differences of more than $50 \%$ between treatments, including $S$. gigantea, Festuca pratensis, Poa trivialis, Alopecurus pratensis, S. canadensis, Vicia hirsuta, Artemisia vulgaris, Holcus lanatus, and Scrophularia nodosa (Table 2). Plots that received glyphosate were dominated by grass species, including $F$. pratensis (mean cover 36.3\%), P. trivialis (23.8\%), and $A$. pratensis (13.8\%). The plots where rototilling was used were covered by $S$. gigantea $(60 \%)$, F. pratensis $(10.8 \%)$, and ruderal species such as $V$. hirsuta (5.25\%), A. vulgaris (6.63\%), and S. nodosa (6.38\%). S. gigantea dominated $(76.3 \%)$ the plots where scalping was applied, with a high proportion of $P$. trivialis (11.3\%), whereas the control plots were dominated by $S$. gigantea (97.5\%; Table 2). The differences were well illustrated by the NMDS ordination analysis. The first NMDS axis separated the plots treated with glyphosate from the others (scalping, rototilling, and control), whereas the second axis was associated with ruderal species cover (Fig. 1). Species with lower contributions in the plots were also taxa occurring exclusively on plots in specific treatments. Lathyrus pratensis, Festuca rubra, Vicia cracca, Veronica chamaedrys, and Plantago lanceolata occurred exclusively on glyphosate plots.

\section{Effect on Species Group Coverage and Grassland Utilisation Values}

The treatments that received fresh hay significantly affected the cover of Solidago spp. $(H=12.12, p=$ $0.007)$, target $(H=10.52, p=0.015)$, and other $(H=9.25$, $p=0.025)$ species, but did not affect the ruderal species group $(H=6.03, p=0.109)$ (Table 3). Glyphosate had the best limiting effect $(0.5 \pm 0.4 \%)$ on Solidago cover. Solidago cover was $65.0 \pm 31.4 \%$ after rototilling and $79.5 \pm 17.1 \%$ after scalping, whereas $99.3 \pm 2.2 \%$ coverage was observed on the control plots. The plots that received glyphosate also exhibited the highest target species coverage ( $84.8 \pm 13.6 \%)$. The target grasses with the highest cover were $F$. pratensis, $P$. trivialis, and A. pratensis (Table 2). These results differed significantly between the control

Table 3. Results of the Kruskal-Wallis analysis ( $H$ and $p$-values), means, and standard deviations of species groups coverage and grassland utilisation indicator values for the treatments. Different letters in a row indicate a significant difference $(p<0.05)$ between groups.

\begin{tabular}{|c|c|c|c|c|c|c|c|}
\hline & & $H$ & $p$ & Scalping & Glyphosate & Rototilling & Control \\
\hline \multirow{4}{*}{ Species groups } & Solidago spp. & 12.12 & $0.007^{*}$ & $79.5 \pm 17.1 \mathbf{a b}$ & $0.5 \pm 0.4 \mathbf{c}$ & $65.0 \pm 31.4 \mathbf{b}$ & $99.3 \pm 2.2 \mathbf{~ a}$ \\
\cline { 2 - 8 } & Target & 10.52 & $0.015^{*}$ & $25.8 \pm 16.0 \mathbf{b}$ & $84.8 \pm 13.6 \mathbf{a}$ & $30 \pm 15.8 \mathbf{b}$ & $11.0 \pm 10.4 \mathbf{b}$ \\
\cline { 2 - 8 } & Ruderal & 6.03 & 0.109 & $7.3 \pm 2.9$ & $4.9 \pm 4.2$ & $15.0 \pm 9.7$ & $3.0 \pm 1.9$ \\
\cline { 2 - 8 } & Other & 9.25 & $0.025^{*}$ & $7.5 \pm 1.3 \mathbf{a}$ & $1.1 \pm 0.6 \mathbf{b}$ & $12.5 \pm 13.1 \mathbf{a}$ & $3.1 \pm 2.9 \mathbf{a b}$ \\
\hline $\begin{array}{c}\text { Grassland utiliza- } \\
\text { tion indicator } \\
\text { values }\end{array}$ & Forage value & 10.85 & $0.013^{*}$ & $3.2 \pm 0.6 \mathbf{a b}$ & $7.5 \pm 0.3 \mathbf{a}$ & $3.4 \pm 0.8 \mathbf{a b}$ & $2.5 \pm 0.5 \mathbf{b}$ \\
\cline { 2 - 8 } & Mowing tolerance & 10.68 & $0.014^{*}$ & $4.7 \pm 0.3 \mathbf{b}$ & $6.6 \pm 0.4 \mathbf{a}$ & $4.4 \pm 0.3 \mathbf{b}$ & $4.3 \pm 0.3 \mathbf{~ b}$ \\
\hline
\end{tabular}


plots $(11.0 \pm 10.4 \%)$ and the scalping and rototilling plots ( $25.8 \pm 16 \%$ and $30 \pm 15.8 \%$, respectively).

Differences in sward quality are shown in Table 3. The foraging value and mowing tolerance varied significantly by treatment $(H=10.85, p=0.013$; and $H=10.68$, $p=0.014$, respectively). The highest forage value was recorded in plots that received glyphosate, where the sward was assessed as high or the best forage value. The quality of the sward was rated between no and little forage value after scalping, rototilling, and in the control plot. Plots that received glyphosate had the highest mowing tolerance. The swards on plots that received the other treatments and the control were sensitive or moderately tolerant to mowing.

\section{Discussion}

It is important to provide the diaspores of meadow species to restore a meadow, which is usually accomplished by sowing a commercial seed mixture of meadow grasses. However, in this case, the restored meadow sward was poor in plant species [42-43] and did not increase biodiversity. Additionally, the F. rubra cultivars typically used to restore grasslands are no more competitive than plants originating from wild seed [44]. Thus, many semi-natural meadow restoration projects spread fresh hay, which contains the seeds of target species [32, 4546]. Our experimental results show that fresh hay was an efficient source of target species propagules, even in grasslands seriously affected by invasive plant species, but the efficiency of target species emergence depends on the method used to remove the alien species.

Using a herbicide can quickly eradicate or limit invasive species [29-30, 47]. Our experiments reveal that Solidago spp. cover decreased rapidly after applying a glyphosate-based herbicide, and the dominant species were $F$. pratensis, A. pratensis, and $P$. trivialis. These perennial grass species are highly competitive and can effectively reduce the occurrence of non-target species $[33,47]$. Other species, such as L. pratensis and F. rubra, along with dominant grasses resulted in good tolerance of mowing and a high forage value for the sward after applying glyphosate.

Seeds of non-target species will germinate if the method used to eradicate alien species causes a soil disturbance $[32,48]$. Our results show a similar effect, as species composition of the swards in the rototilling and scalping treatments included a number of undesired species, such as Equisetum arvense and Elymus repens. Additionally, the rototiller caused species such as A. vulgaris, S. nodosa, Rumex crispus, Epilobium palustre, Cirsium arvense, and Oxalis europea to achieve greater coverage than those observed in the scalping-treated plots. The rototiller also resulted in less $S$. gigantea and target species coverage compared to that in plots that received the herbicide. In both cases, the sward had a low forage value and was sensitive to cutting because of species composition.
Consequently, further mowing would promote coverage of unwanted species tolerant of cutting. These species are ultimately replaced by grassland species; however, this process can be prolonged.

Solidago spp. coverage was $99.3 \%$ in the control plots. The large percentage of Solidago spp. and the small number of target species resulted in the lowest sward utility value and was rated as no or low value as animal feed. Despite the expectation that fresh hay would reduce growth and the emergence of Solidago sprouts, we observed dense cover by Solidago spp., indicating that applying fresh hay alone cannot eradicate Solidago spp.

Eradicating Solidago spp. that invade natural and seminatural ecosystems is difficult. Combining treatments is only the first stage of renovating a meadow ecosystem. The next step depends on annual mowing and removal of biomass, which help control unwanted, sensitive species, including invasive Solidago spp. The fastest result was achieved using the herbicide and is the cheapest method for eradicating invasive species [9]. However, it has a negative impact on the environment and native species [49-50]. This method is also restricted in protected areas and is only used with treatments that disturb soil structure. However, restoring valuable communities using mechanical methods to eliminate invasive species requires more time.

\section{Acknowledgements}

We thank Prof. Vilém Pavlů for useful comments, $\mathrm{PhD}$ Zygmunt Kacki for the indication of donor site and assistance in collecting fresh hay and Mr. Janusz Urbański for assistance in fieldwork during the whole experiment course. This study was supported by Wrocław University of Environmental and Life Sciences.

\section{References}

1. MEYER G., CLARE R., WEBER E. An experimental test of the evolution of increased competitive ability hypothesis in goldenrod, Solidago gigantea. Oecologia, 144, 299, 2005.

2. BYERS J.E., REICHARD S., RANDALL J.M., PARKER I., SMITH C.S., LONSDALE W.M., ATKINSON I.A.E., SEASTEDT T., WILLIAMSON M., CHORNESKY E., HAYES D. Directing research to reduce the impacts of nonindigenous species. Conserv. Biol., 16, 630, 2002.

3. SIMBERLOFF D., MARTIN J.L., GENOVESI P., MARIS V., WARDLE D.A., ARONSON J., COURCHAMP F., GALIL B., GARCÍA-BERTHOU E., PASCAL M., PYŠEK P., SOUSA R., TABACCHI E., VILÀ M. Impacts of biological invasions: what's what and the way forward. Trends Ecol. Evol., 28, 58, 2013.

4. HABEL J.C., DENGLER J., JANIŠOVÁ M., TÖRÖK P., WELLSTEIN C., WIEZIK M. European grassland ecosystems: Threatened hotspots of biodiversity. Biodivers. Conserv., 22, 2131, 2013.

5. JOYCE C.B. Ecological consequences and restoration potential of abandoned wet grasslands. Ecol. Eng. 66, 91, 2014. 
6. EEA Mapping and assessing the condition of Europe's ecosystems: progress and challenges. European Environmental Agency Report No 3/2016.

7. PETERS V.E., CAMPBELL K.U., DIENNO G., GARCÍA M., LEAK E., LOYKE C., OGLE M., STEINLY B., CRIST T.O. Ants and plants as indicators of biodiversity, ecosystem services, and conservation value in constructed grasslands. Biodivers. Conserv., 25, 1, 2016.

8. ORŁOWSKI G. Endangered and declining bird species of abandoned farmland in south-western Poland. Agric. Ecosyst. Environ., 111, 231, 2005.

9. SZYMURA M., SZYMURA T.H., WOLSKI K. Invasive Solidago species: how large area do they occupy and what would be the cost of their removal? Pol. J. Ecol., 64, 25, 2016.

10. VALKÓ O., DEÁK B., TÖRÖK P., KELEMEN A., MIGLÉCZ T., TÓTH K., TÓTHMÉRÉSZ B. Abandonment of croplands: problem or chance for grassland restoration? Case studies from Hungary. - Ecosyst. Health Sustain., 2, $1,2016$.

11. PEJCHAR L., MOONEY H. Invasive species, ecosystem services and human well-being. Trends Ecol. Evol., 24, 497, 2009.

12. MOROŃ D., LENDA M., SKÓRKA P., SZENTGYÖRGYI H., SETTELE J., WOYCIECHOWSKI M. Wild pollinator communities are negatively affected by invasion of alien goldenrods in grassland landscapes. Biol. Conserv., 142, 1322, 2009.

13. FENESI A., VÁGÁSI C.I., BELDEAN M., FÖLDESI R., KOLCSÁR L.P., SHAPIRO J.T., TÖRÖK E., KOVÁCSHOSTYÁNSZKI A. Solidago canadensis impacts on native plant and pollinator communities in different-aged old fields. Basic Appl. Ecol., 16, 335, 2015.

14. SZYMURA M., SZYMURA T.H., KREITSCHITZ A. Morphological and cytological diversity of goldenrods (Solidago L. and Euthamia Nutt.) from south-western Poland. Biodiv. Res. Conserv., 38, 41, 2015.

15. WEBER E. The dynamics of plant invasions: A case study of three exotic goldenrod species (Solidago L.) in Europe. J. Biogeogr., 25, 147, 1998.

16. WEBER E., JAKOBS G. Biological flora of central Europe: Solidago gigantea Aiton. Flora, 200, 109, 2005.

17. KABUCE N., PRIEDE N. NOBANIS - Invasive Alien Species Fact Sheet - Solidago canadensis. From: Online Database of the North European and Baltic Network on Invasive Alien Species NOBANIS, 2012. Available online: http:// www.nobanis.org (accesed on 11/09/2016).

18. SZYMURA M., SZYMURA T.H. Historical contingency and spatial processes rather than ecological niche differentiation explain the distribution of invasive goldenrods (Solidago and Euthamia). Plant Ecol., 217, 565, 2016.

19. SZYMURA M., SZYMURA T.H. Growth, phenology, and biomass allocation of alien Solidago species in central Europe. Plant Species Biol., 30, 245, 2014.

20. LI W., ZHANG C., PENG C. Responses of Soil Microbial Community Structure and Potential Mineralization Processes to Solidago canadensis Invasion. Soil Sci., 177, 433, 2012.

21. LIAO M., XIE X., PENG Y., CHAI J., CHEN N. Characteristics of soil microbial community functional and structure diversity with coverage of Solidago canadensis L. J. Cent. South. Univ., 20, 749, 2013.

22. QUIST C.W., VERVOORT M.T.W., VAN MEGEN H., GORT G., BAKKER J., VAN DER PUTTEN W.H., HELDER J. Selective alteration of soil food web components by invasive giant goldenrod Solidago gigantea in two distinct habitat types. Oikos 123, 837, 2014.

23. REID A.M., MORIN L., DOWNEY P.O., FRENCH K., VIRTUE J.G. Does invasive plant management aid the restoration of natural ecosystems? Biol. Conserv., 142, 2342, 2009.

24. MEYER A.H., SCHMID B. Seed dynamics and seedling establishment in the invading perennial Solidago altissima under different experimental treatments. J. Ecol., 87, 28, 1999.

25. SAITO T.I., TSUYUZAKI S. Response of riparian vegetation to the removal of the invasive forb, Solidago gigantea, and its litter layer. Weed Biol. Manag., 12, 63, 2012

26. DELAHUNTY K.M., JOHNSTON J.C. Strategies for Weed Management in Organic Hops, a Perennial Crop. Agron. J., 107, 634, 2015.

27. MONTY A., EUGENE M., MAHY G. Vegetative regeneration capacities of five ornamental plant invaders after shredding. Environ. Manage., 55, 423, 2015.

28. GUO S.L., JIANG H.W., FANG F., CHEN G.Q. Influences of herbicides, uprooting and use as cut flowers on sexual reproduction of Solidago canadensis. Weed Res., 49, 291, 2009.

29. PAYNE K.K., BRADLEY K.W. Herbicidal Control of Tall Goldenrod in Tall Fescue Hayfields. Forage and Grazinglands 8, 2010.

30. DOMARADZKI K., BADOWSKI M. Możliwość chemicznego ograniczania występowania Solidago gigantea Aiton na terenach odłogowanych. Zesz. Nauk. UP Wroc., Rol., 584, 17, 2012 [In Polish].

31. GORNISH E.S., AMBROZIO DOS SANTOS P. Invasive species cover, soil type, and grazing interact to predict longterm grassland restoration success. Restor. Ecol., 24, 222, 2016.

32. HÖLZEL N., OTTE A. Restoration of a species-rich flood meadow by topsoil removal and diaspore transfer with plant material. Appl. Veg. Sci., 6, 131, 2003.

33. DONATH T.W., BISSELS S., HÖLZEL N., OTTE A. Large scale application of diaspore transfer with plant material in restoration practice - Impact of seed and microsite limitation. Biol. Conserv., 138, 224, 2007.

34. KLIMKOWSKA A., VAN DIGGELEN R., BAKKER J.P., GROOTJANS A.P. Wet meadow restoration in Western Europe: A quantitative assessment of the effectiveness of several techniques. Biol. Conserv., 140, 318, 2007.

35. HAMMER Ø., HARPER D.A.T., RYAN P.D. PAST: Paleontological Statistics Software Package for education and data analysis. Palaeontol. Electron., 4, 1, 2001.

36. TER BRAAK C.J.F., S̆MILAUER P. Canoco Reference Manual and User's Guide: Software for Ordination (version 5.0). Microcomputer Power, Ithaca, NY, USA, 2012.

37. CLARKE K.R. Non-parametric multivariate analyses of changes in community structure. Aust. J. Ecol., 18, 117, 1993.

38. ONOFRI A., CARBONELL E.A., PIEPHO H.P., MORTIMER A.M., COUSENS R.D. Current statistical issues in Weed Research. Weed Res., 50, 5, 2010.

39. KLOTZ S., KÜHN I., DURKA W. BIOLFLOR - Eine Datenbank zu biologisch-ökologischen Merkmalen der Gefäßpflanzen in Deutschland. Schriftenreihe für Vegetationskunde 38, 2002.

40. MATUSZKIEWICZ W. Przewodnik do oznaczania zbiorowisk roślinnych Polski. Państwowe Wydawnictwo Naukowe PWN, Warszawa, 2008 [In Polish].

41. StatSoft, Inc. STATISTICA (data analysis software system), version 12. www.statsoft.com, 2013. 
42. CONRAD M.K., TISCHEW S. Grassland restoration in practice: Do we achieve the targets? A case study from Saxony-Anhalt/Germany. Ecol. Eng., 37, 1149, 2011.

43. LENCOVÁ K., PRACH K. Restoration of hay meadows on ex-arable land: commercial seed mixtures vs. spontaneous succession. Grass Forage Sci., 66, 265, 2011.

44. WALKER E.A., CONRADI T., MEIMBERG H., KOLLMANN J. Seed selection for grassland restoration: competitive effect of a dominant grass is mediated by seed source and nutrient availability. Restor. Ecol., 23, 261, 2015.

45. EDWARDS A.R., MORTIMER S.R., LAWSON C.S., WESTBURY D.B., HARRIS S.J., WOODCOCK B.A., BROWN V.K. Hay strewing, brush harvesting of seed and soil disturbance as tools for the enhancement of botanical diversity in grasslands. Biol. Conserv., 134, 372, 2007.

46. SCHMIEDE R., RUPRECHT E., LUTZ ECKSTEIN R., OTTE A., DONATH T.W. Establishment of rare flood meadow species by plant material transfer: Experimental tests of threshold amounts and the effect of sowing position. Biol. Conserv., 159, 222, 2013.

47. NYAMAI P.A., PRATHER T.S., WALLACE J.M. Evaluating restoration methods across a range of plant communities dominated by invasive annual grasses to native perennial grasses. Invasive Plant Sci. Manag., 4, 306, 2011.

48. WELLSTEIN C., OTTE A., WALDHARDT R. Seed bank diversity in mesic grasslands in relation to vegetation type, management and site conditions. J. Veg. Sci., 18, 153, 2007.

49. WAGNER N., REICHENBECHER W., TEICHMANN H., TAPPESER B., LÖTTERS S. Questions concerning the potential impact of glyphosate- based herbicides on amphibians. Environ. Toxicol. Chem., 32, 1688, 2013.

50. BOUTIN C., STRANDBERG B., CARPENTER D., MATHIASSEN S.K., THOMAS P.J. Herbicide impact on non-target plant reproduction: What are the toxicological and ecological implications? Environ. Pollut., 185, 295, 2014.

Appendix 1. Results of the SIMPER analysis. Species contribution of the differences between treatments and the cumulative percentages (cumulative). The values in columns for particular treatments (scalping, glyphosate, rototilling, and control) show the mean cover of the species in a given treatment. Species affected differences in the sward after fresh hay was transferred and the use of selected treatments. The analysis was performed on square root transformed data. The means of the raw data are shown in parenthesis.

\begin{tabular}{|c|c|c|c|c|c|c|c|c|c|c|}
\hline Taxon & $\begin{array}{c}\text { Contrib. } \\
\%\end{array}$ & $\begin{array}{c}\text { Cumulative } \\
\%\end{array}$ & \multicolumn{2}{|c|}{ Scalping } & \multicolumn{2}{|c|}{ Glyphosate } & \multicolumn{2}{|c|}{ Rototilling } & \multicolumn{2}{|c|}{ Control } \\
\hline Solidago gigantea & 14.65 & 14.65 & 8.70 & (76.30) & 0.60 & $(0.50)$ & 7.50 & $(60.00)$ & 9.87 & $(97.50)$ \\
\hline Festuca pratensis & 9.68 & 24.33 & 0.60 & $(0.75)$ & 5.97 & $(36.30)$ & 3.03 & $(10.80)$ & 0.35 & $(0.50)$ \\
\hline Poa trivialis & 5.63 & 29.96 & 3.16 & (11.30) & 4.74 & $(23.80)$ & 2.11 & $(4.50)$ & 1.88 & $(5.25)$ \\
\hline Alopecurus pratensis & 5.49 & 35.46 & 0.56 & $(1.25)$ & 3.51 & $(13.80)$ & - & - & 0.25 & $(0.25)$ \\
\hline Solidago canadensis & 3.71 & 39.16 & 1.55 & $(3.25)$ & - & - & 2.24 & $(5.00)$ & 1.16 & $(1.75)$ \\
\hline Vicia hirsuta & 3.54 & 42.70 & 1.91 & $(5.00)$ & 1.43 & $(3.77)$ & 2.16 & $(5.25)$ & 1.44 & $(2.38)$ \\
\hline Artemisia vulgaris & 3.25 & 45.96 & 0.61 & $(0.65)$ & - & - & 2.19 & $(6.63)$ & 0.08 & $(0.03)$ \\
\hline Holcus lanatus & 3.16 & 49.11 & 0.60 & $(0.50)$ & 2.34 & $(5.75)$ & 1.34 & $(2.13)$ & 0.60 & $(0.50)$ \\
\hline Scrophularia nodosa & 2.69 & 51.80 & 0.08 & $(0.03)$ & 0.08 & $(0.03)$ & 1.85 & $(6.38)$ & 0.25 & $(0.25)$ \\
\hline Rumex crispus & 2.59 & 54.39 & 0.50 & $(0.50)$ & - & - & 1.40 & $(4.50)$ & 0.51 & $(0.40)$ \\
\hline Arrhenatherum elatius & 2.55 & 56.93 & 1.06 & $(1.50)$ & - & - & 0.99 & $(2.00)$ & 0.68 & $(0.63)$ \\
\hline Cerastium holosteoides & 1.97 & 58.90 & 0.26 & $(0.15)$ & 1.16 & $(2.00)$ & 0.53 & $(0.38)$ & 0.26 & $(0.15)$ \\
\hline Epilobium palustre & 1.914 & 60.81 & 0.53 & $(0.38)$ & 0.43 & $(0.38)$ & 0.99 & $(2.00)$ & 0.35 & $(0.25)$ \\
\hline Cirsium arvense & 1.85 & 62.67 & 0.61 & $(0.88)$ & 0.26 & $(0.15)$ & 0.91 & $(1.50)$ & - & - \\
\hline Calamagrostis epigeios & 1.80 & 64.47 & 0.60 & $(1.25)$ & 0.18 & $(0.13)$ & 0.25 & $(0.25)$ & 0.56 & $(1.25)$ \\
\hline Rubus sp. & 1.73 & 66.20 & 0.71 & $(2.00)$ & - & - & 0.18 & $(0.13)$ & 0.35 & $(0.50)$ \\
\hline Agrostis gigantea & 1.70 & 67.90 & 0.79 & $(2.50)$ & - & - & - & - & 0.56 & $(1.25)$ \\
\hline Equisetum arvense & 1.70 & 69.60 & 1.16 & $(1.75)$ & 0.43 & $(0.28)$ & 0.96 & $(1.38)$ & 0.85 & $(0.75)$ \\
\hline Phleum pratense & 1.64 & 71.24 & 0.35 & $(0.50)$ & - & - & 1.04 & $(1.50)$ & - & - \\
\hline Elymus repens & 1.63 & 72.88 & 0.56 & $(1.25)$ & - & - & 0.74 & $(1.38)$ & 0.08 & $(0.03)$ \\
\hline Anthoxanthum odoratum & 1.63 & 74.51 & 0.25 & $(0.25)$ & 0.86 & $(1.13)$ & 0.35 & $(0.25)$ & - & - \\
\hline Deschampsia caespitosa & 1.49 & 76.00 & 0.79 & $(2.50)$ & - & - & - & - & 0.35 & $(0.50)$ \\
\hline Trifolium dubium & 1.41 & 77.41 & 0.35 & $(0.25)$ & 0.18 & $(0.13)$ & 0.56 & $(1.25)$ & 0.18 & $(0.13)$ \\
\hline Oxalis europaea & 1.41 & 78.81 & 0.18 & $(0.13)$ & - & - & 0.93 & $(1.25)$ & 0.08 & $(0.03)$ \\
\hline
\end{tabular}


Appendix 1. Continued.

\begin{tabular}{|c|c|c|c|c|c|c|c|c|c|c|}
\hline Urtica dioica & 1.35 & 80.17 & 0.35 & $(0.50)$ & 0.18 & $(0.13)$ & 0.35 & $(0.25)$ & 0.43 & $(0.38)$ \\
\hline Alchemilla monticola & 1.31 & 81.48 & 0.68 & $(0.63)$ & 0.18 & $(0.13)$ & 0.18 & $(0.13)$ & 0.43 & $(0.38)$ \\
\hline Vicia tetrasperma & 1.19 & 82.66 & 0.18 & $(0.13)$ & 0.71 & $(0.75)$ & - & - & 0.08 & $(0.03)$ \\
\hline Taraxacum officinale & 1.08 & 83.74 & 0.78 & $(0.63)$ & 0.18 & $(0.13)$ & 0.53 & $(0.38)$ & 0.53 & $(0.38)$ \\
\hline Ranunculus acris & 1.02 & 84.76 & 0.53 & $(0.38)$ & 0.71 & $(0.50)$ & 0.53 & $(0.38)$ & 0.18 & $(0.13)$ \\
\hline Campanula patula & 0.89 & 85.66 & 0.35 & $(0.25)$ & 0.18 & $(0.13)$ & 0.34 & $(0.18)$ & 0.08 & $(0.03)$ \\
\hline Poa pratensis & 0.87 & 86.53 & 0.35 & $(0.50)$ & - & - & 0.18 & $(0.13)$ & 0.18 & $(0.13)$ \\
\hline Carex hirta & 0.86 & 87.39 & 0.53 & $(0.63)$ & - & - & 0.18 & $(0.13)$ & - & - \\
\hline Plantago major & 0.75 & 88.14 & 0.18 & $(0.13)$ & - & - & 0.43 & $(0.38)$ & - & - \\
\hline Lychnis flos-cuculi & 0.714 & 88.86 & 0.35 & $(0.25)$ & 0.08 & $(0.03)$ & 0.18 & $(0.13)$ & - & - \\
\hline Rumex acetosa & 0.71 & 89.57 & - & - & 0.33 & $(0.28)$ & 0.18 & $(0.13)$ & 0.08 & $(0.03)$ \\
\hline Heracleum sphondylium & 0.67 & 90.24 & 0.18 & $(0.13)$ & - & - & 0.08 & $(0.03)$ & 0.25 & $(0.25)$ \\
\hline Carex pallescens & 0.66 & 90.89 & 0.35 & $(0.50)$ & - & - & - & - & 0.16 & $(0.05)$ \\
\hline Mentha arvensis & 0.65 & 91.54 & 0.08 & $(0.03)$ & - & - & 0.43 & $(0.75)$ & - & - \\
\hline Galium aparine & 0.63 & 92.16 & 0.18 & $(0.13)$ & 0.18 & $(0.13)$ & 0.18 & $(0.13)$ & - & - \\
\hline Dactylis glomerata & 0.62 & 92.79 & - & - & - & - & 0.33 & $(0.28)$ & 0.18 & $(0.13)$ \\
\hline Avenula pubescens & 0.57 & 93.36 & - & - & - & - & - & - & 0.35 & $(0.50)$ \\
\hline Stachys palustris & 0.57 & 93.92 & - & - & - & - & 0.26 & $(0.15)$ & 0.18 & $(0.12)$ \\
\hline Trifolium pratense & 0.48 & 94.40 & - & - & 0.18 & $(0.13)$ & 0.18 & $(0.13)$ & - & - \\
\hline Lathyrus pratensis & 0.39 & 94.78 & - & - & 0.26 & $(0.15)$ & - & - & - & - \\
\hline Lysimachia nummularia & 0.37 & 95.15 & 0.08 & $(0.03)$ & - & - & - & - & 0.18 & $(0.13)$ \\
\hline Festuca rubra & 0.36 & 95.51 & - & - & 0.25 & $(0.25)$ & - & - & - & - \\
\hline Prunus sp. & 0.35 & 95.86 & - & - & 0.24 & $(0.08)$ & - & - & - & - \\
\hline Achillea millefolium & 0.33 & 96.18 & 0.25 & $(0.25)$ & - & - & - & - & - & - \\
\hline Erigeron annuиs & 0.33 & 96.51 & - & - & - & - & 0.26 & $(0.15)$ & - & - \\
\hline Galium mollugo & 0.29 & 96.80 & - & - & - & - & - & - & 0.18 & $(0.13)$ \\
\hline Vicia cracca & 0.27 & 97.06 & - & - & 0.18 & $(0.13)$ & - & - & - & - \\
\hline Sonchus asper & 0.27 & 97.33 & - & - & 0.18 & $(0.13)$ & - & - & - & - \\
\hline Vicia species & 0.26 & 97.59 & - & - & 0.18 & $(0.13)$ & - & - & - & - \\
\hline Ranunculus repens & 0.26 & 97.85 & - & - & - & - & - & - & 0.18 & $(0.13)$ \\
\hline Veronica chamaedrys & 0.25 & 98.10 & - & - & 0.18 & $(0.13)$ & - & - & - & - \\
\hline Plantago lanceolata & 0.25 & 98.35 & - & - & 0.18 & $(0.13)$ & - & - & - & - \\
\hline Poa palustris & 0.25 & 98.60 & - & - & - & - & - & - & 0.18 & $(0.13)$ \\
\hline Leucanthemum vulgare & 0.24 & 98.85 & - & - & - & - & 0.18 & $(0.13)$ & - & - \\
\hline Luzula multiflora & 0.24 & 99.08 & 0.18 & $(0.13)$ & - & - & - & - & - & - \\
\hline Stellaria graminea & 0.23 & 99.32 & 0.18 & $(0.13)$ & - & - & - & - & - & - \\
\hline Trifolium repens & 0.23 & 99.54 & - & - & - & - & 0.18 & $(0.13)$ & - & - \\
\hline Lolium perenne & 0.23 & 99.77 & - & - & - & - & 0.18 & $(0.13)$ & - & - \\
\hline Acer pseudoplatanus & 0.13 & 99.89 & 0.08 & $(0.03)$ & - & - & - & - & - & - \\
\hline Trifolium hybridum & 0.11 & 100.00 & - & - & - & - & 0.08 & $(0.03)$ & - & - \\
\hline
\end{tabular}

